\title{
Pelatihan Akuntansi Bank Transaksi Back Office Bank Konvensional Bagi SMK Unitomo Surabaya
}

\author{
Evi Sistiyarini*1, Herizon², Carolyn Lukita Sembiring ${ }^{3}$ \\ 1,2STIE Perbanas Surabaya \\ ${ }^{3}$ Program Studi Sarjana Manajemen, STIE Perbanas Surabaya \\ ${ }^{3}$ Universitas Buana Perjuangan Karawang \\ ${ }^{3}$ Program Studi Sarjana Akuntansi, Universitas Buana Perjuangan Karawang \\ *e-mail: evi.sistiyarini@perbanas.ac.id ${ }^{1}$, herizon@perbanas.ac.id ${ }^{2}$ lukita.carolyns@gmail.com $^{3}$
}

\begin{abstract}
Senior Vocational School of Unitomo Surabaya is one of scholl in Surabaya that have cooperated with STIE Perbanas Surabaya. One of majoring in Senior Vocational School of Unitomo Surabaya is accounting. There are two problems faced Senior Vocational School of Unitomo Surabaya. They are the limited learning of banking accounting and the accounting learning process is still done manually. This community service activity is carried out by providing banking accounting training of back office transaction(current account in Conventional Bank for Senior Vocational School of Unitomo Surabaya. This activity provides additional knowledfe for teachers and students of Senior Vocational School of Unitomo Surabaya about back office transaction in Conventional Bank both in theory or practice.
\end{abstract}

Keywords: Accouting, Bank, Conventional, Back Office

\begin{abstract}
Abstrak
SMK Unitomo Surabaya merupakan salah satu sekolah yang telah melakukan kwgiTn kerjasama dengan STIE Perbanas Surabaya. Salah satu jurusan yang ada di SMK Unitomo Surabaya adalah jurusan akuntansi. Terdapat dua permasalahan yang dihadapi oleh SMK Unitomo Surabaya yaitu adanya keterbatasan pembelajaran akuntansi perbankan serta proses pembelajaran akuntansi masih dilakukan secara manual. Kegiatan pengabdian masyarakat ini dilakukan dengan memberikan pelatihan akuntansi bank transaksi back office (giro, deposito, kliring dan transfer) bank konvensional bagi SMK Unitomo Surabaya. Kegiatan ini memberikan tambahan pengetahuan bagi guru dan siswa SMK Unitomo Surabaya mengenai transaksi transaksi back office bank konvensional baik secara teori maupun secara praktek.
\end{abstract}

Kata kunci: Akuntansi, Bank, Konvensional, Back Office

\section{PENDAHULUAN}

Industri perbankan merupakan industri yang mengalami perkembangan yang cukup pesat. Perkembangan regulasi yang dibuat oleh regulator tetap diikuti oleh dunia perbankan. Hal ini dilakukan agar industri perbankan menjadi industri yang sehat. Dalam mendukung hal tersebut, maka diperlukan juga Sumber Daya Manusia yang memiliki kemampuan yang baik. Sumber Daya Manusia tersebut dapat diperoleh dari lulusan-lusan siswa SMA/SMK/Perguruan Tinggi yang memiliki kompetensi yang baik.

SMK Unitomo Surabaya merupakan salah satu SMK di Surabaya yang telah melakukan kerjasama dengan STIE Perbanas Surabaya. Lokasi SMK Unitomo berada di satu lingkungan dengan Kampus Universitas Unitomo yang berdekatan lokasinya dengan STIE Perbanas Surabaya. SMK Unitomo Surabaya memiliki 7 jurusan yaitu jurusan administrasi perkantoran, akuntansi, multimedia, teknologi komputer jaringan, teknik pengolahan pangan, teknik pengolahan mutu dan animasi.

Permasalahan yang dihadapi oleh SMK Unitomo Surabaya adalah terbatasnya pembelajaran akuntansi perbankan. Hal ini karena SMK Unitomo masih belum memiliki jurusan perbankan sehingga pembelajaran akuntansi masih terbatas pada akuntansi perusahaan. Permasalahan kedua yang dihadapi oleh SMK Unitomo Surabaya adalah proses pembelajaran akuntansi yang masih dilakukan secara manual. Hal ini karena SMK Unitomo Surabaya belum memiliki laboratorium bank untuk proses pembelajaran secara langsung sehingga para siswa 
belum memiliki gambaran transaksi yang ada di bank konvensional. Proses pembelajaran merupakan salah satu komponen penting bagi kualitas pedidikan (Intihapsari, V \& Hendroanto, A, 2017). Saat ini, guru-guru SMK Unitomo Surabaya, belum banyak mendapatkan update informasi terbaru tentang akuntansi perbankan dan praktek transaksi bank konvensional bagian back office.

Kegiatan pelatihan untuk guru tingkat sekolah telah dilakukan oleh pengabdi sebelumnya. Sadar, M dkk (2018) melakukan kegiatan pengabdian masyarakat berupa pelatihan dan sosialisasi sistem informasi keuangan pada Sekolah Islam Terpadu Pekanbaru. Hasil pengabdian menunjukkan bahwa dengan metode pelatihan dan sosialisasi, pengabdi telah berhasil melakukan transfer knowledge kepada mitra. Pada kegiatan pengabdian masyarakat telah dilakukan pengujian kuesioner dengan menggunakan Skala Guttman untuk dua kali kegiatan yaitu sebelm dan setelah kegiatan pengabdian masyarakat.

Nuris, D.M dkk (2018) melakukan kegiatan pengabdian kepada masyarakat tentang pelatihan penyusunan perangkat pembelajaran berbasis TIK bagi guru Akuntansi SMK. Hasil pengabdian masyarakat menunjukkan bahwa perangkat pembelajaran berbasis online sangat diperlukan di era revolusi industri 4.0 yang didukung dengan teknologi informasi dan komunikasi di bidang pendidikan.

Intihapsari, V \& Hendroanto, A, (2017) melakukan kegiatan pengabdian masyarakat tentang pelatihan pengembangan media pembelajaran flash guru SMA/SMK Muhammadiyah Se Kabupaten Gunungkidul. Hasil pengabdian menunjukkan bahwa kegiatan pelatihan berjalan dengan baik dan memiliki respon yang baik dari peserta yang ditunjukkan hasil nilai evaluasi yang baik. Selain itu, kendala yang dihadapi terletak pada jarak dan keterbatasan waktu. Onasis, D dkk (2017) juga membuktikan bahwa kegiatan pengabdian dapat membawa pemahaman dan penerapan atas penyusunan dan penyajian laporan keuangan berbasis SAK ETAP bagi UMKM. Hasil pengabdian masyarakat yang dilakukan oleh Haryani, S (2011) menunjukkan bahwa peserta memperoleh pengetahuan, wawasan dan ketrampilan yang baik untuk pembelajaran berbasis masalah.

\section{METODE} berikut:

Metode pelaksanaan kegiatan pengabdian masyarakat ini terdiri dari tahapan sebagai

\section{a) Mengidentifikasi permasalahan mitra}

Dalam tahapan ini telah dilakukan pengidentifikasian permasalahan yang dihadapi oleh mitra dan langkah-langkah yang diperlukan untuk menyelesaikan permasalahan tersebut. Analisis kebutuhan dikaitkan dengan kebutuhan guru dan siswa SMK untuk memenuhi kebutuhan dalam lapangan pekerjaan (Utami, S dkk, 2016).

\section{b) Pelaksanaan Pelatihan}

Materi yang disampaikan pada saat pelatihan terdiri dari materi pengenalan operasional bank konvensional dan transaksi bagian back office yaitu bagian giro, bagian deposito, bagian transfer dan bagian kliring baik secara teori maupun secara praktek (Instruktur Laboratorium Bank, 2018). Peserta diberikan pengetahuan tentang transaksi back office bank konvensional mulai dari cara mengisi slip, membuat jurnal transaksi dan melakukan input transaksi di komputer.

c) Evaluasi Kegiatan

Setelah pelaksanaan kegiatan, maka dilakukan evaluasi terhadap kegiatan pelatihan dan mengidentifikasi kendala yang dihadapi selama pelatihan. Evaluasi dilakukan pada saat sebelum dan sesudah kegiatan (Utaminingsih, 2019). Kegiatan evaluasi dilakukan dengan tujuan untuk melihat seberapa jauh pengatahuan peserta pengabdian masyarakat ini dalam memahami materi pelatihan yang diberikan (Hadiyati dkk, 2017). Selain itu, kegiatan evaluasi juga diperlukan untuk mengetahui efektifitas kegiatan pengabdian tersebut dilakukan (Karyono, 2010). 


\section{HASIL DAN PEMBAHASAN}

Kegiatan pelatihan ini dilaksanakan selama dua hari dan diikuti oleh sepuluh orang yang terdiri dari guru dan siswa SMK Unitomo Surabaya. Materi yang disampaikan pada hari pertama terdiri dari materi tentang pengenalan operasional bank konvensional serta materi teori tentang bagian giro, deposito, transfer dan kliring. Sedangkan pada hari kedua, materi yang disampaikan mengenai praktek transaksi giro, deposito, transfer dan kliring mulai cara mengisi transaksi sampai dengan melakukan input transaksi di komputer. Adapun jenis transaksi yang disampaikan meliputi pembukaan rekening giro dan deposito, pencairan rekening deposito serta pemindahbukuan, tranaksi pengiriman dana (transfer) sesama bank maupun beda bank serta keterkaitan transaksi dengan bagian-bagian yang lain. Peserta diperkenalkan dengan media / slip yang digunakan serta software yang digunakan untuk transaksi di bagian giro, deposito, transfer dan kliring.

Pada kegiatan ini dilakukan dua kali test yaitu pre test dan post test. Pre test merupakan tes yang dilakukan sebelum kegiatan berlangsung. Sedangkan pre test merupakan tes yang dilakukan setelah kegiatan pelatihan selesai dilaksanakan.

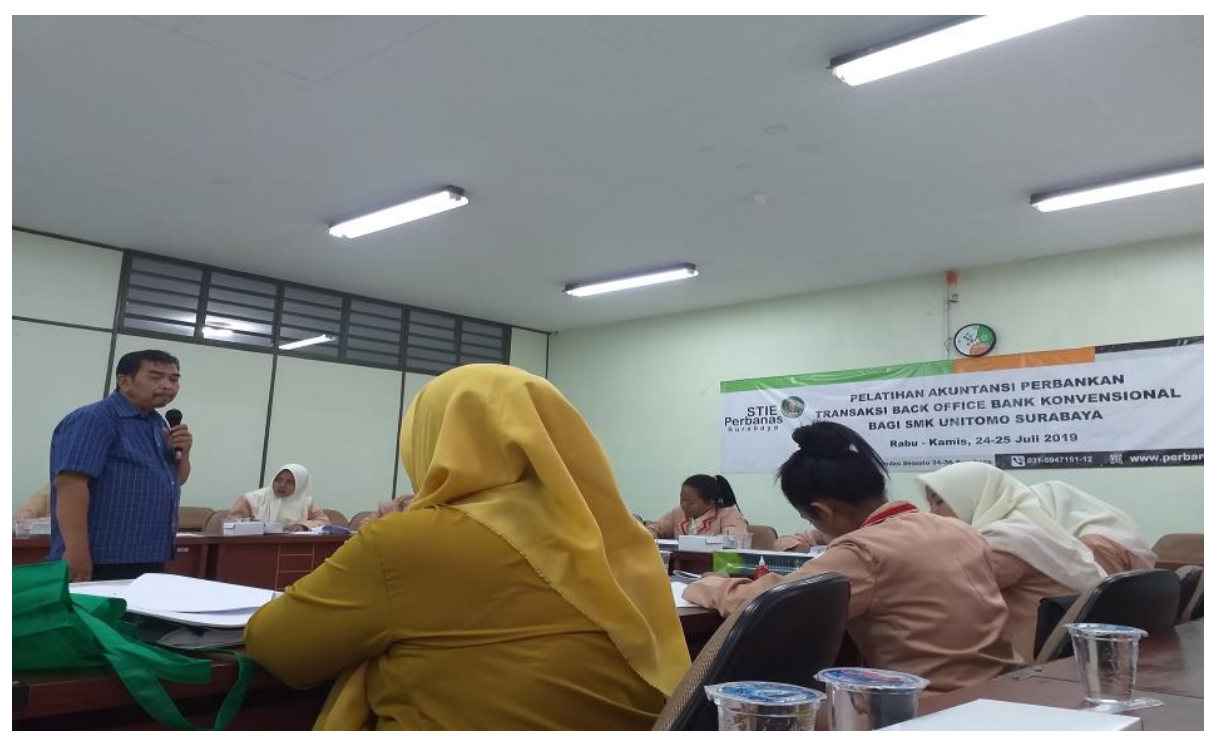

Gambar 1. Kegiatan Pelatihan Hari Pertama

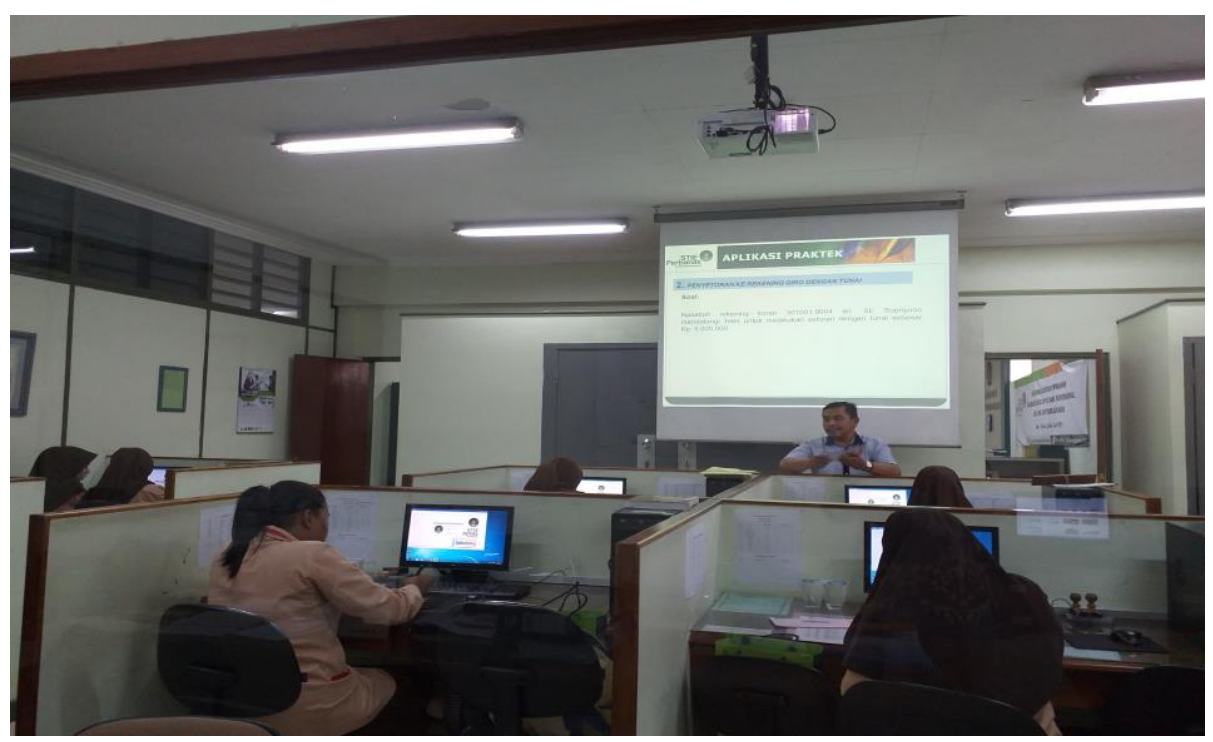

Gambar 2. Kegiatan Pelatihan Hari Kedua 
Indikator keberhasilan dari kegiatan pelatihan ini adalah minimal 70\% peserta pelatihan memperoleh nilai post test yang lebih tinggi dari nilai pre test. Hasil penilaian post test dan pre test menunjukkan bahwa dari 10 peserta pelatihan terdapat 8 peserta pelatihan $(80 \%)$ telah memiliki nilai post test yang lebih tinggi dari nilai pre test. Sedangkan 2 peserta $(20 \%)$ memiliki nilai post test yang lebih rendah dibandingkan dengan nilai pre test. Hasil ini menunjukkan bahwa peserta pelatihan memiliki pemahaman yang cukup baik setelah dilakukan kegiatan pelatihan.

Pada pelatihan ini, dilakukan evaluasi terhadap 3 komponen yaitu penyelenggaraan, fasilitas / konsumsi dan materi. Komponen penyelenggaraan terdiri dari 3 item penilaian yaitu metode pelatihan, koordinasi pelaksanaan, dan kerjasama panitia dengan peserta. Komponen fasilitas/komsusmsi terdiri dari 5 item yaitu kondisi ruangan, pengaturan tempat duduk, sound system, seminar kit dan konsumsi. Sedangkan komponen konsumsi terdiri dari 4 item yaitu kualitas materi secara keseluruhan, aktualisasi materi, kebaruan materi dan kualitas pembawa materi. Berdasarkan hasil evaluasi pada tabel 1 dapat diketahui bahwa masing-masing item penilaian memiliki skor di atas 4,30 dan rata-rata untuk masing-masing komponen di atas 4,50. Hal ini menunjukkan bahwa penilaian pelaksanaan pelatihan ini dinilai sangat baik oleh para peserta.

Tabel 1. Hasil Evaluasi Pelaksanaan

\begin{tabular}{lll}
\hline No & Jenis Penilaian & Rata-Rata \\
\hline PENYELENGGARAAN & $\mathbf{4 . 6 0}$ \\
1 & Metode Pelatihan & 4.40 \\
2 & Koordinasi Pelaksanaan & 4.60 \\
3 & Kerjasama panitia dengan peserta & 4.80 \\
FASILITAS/ KONSUMSI & $\mathbf{4 . 6 0}$ \\
\multicolumn{2}{l}{ Kondisi Ruangan } & 5.00 \\
5 & Pengaturan Tempat Duduk & 4.60 \\
6 & Sound System & 4.40 \\
7 & Seminar Kit (Materi) & 4.40 \\
8 & Konsumsi & 4.60 \\
MATERI & $\mathbf{4 . 5 3}$ \\
9 & Kualitas Materi Secara Keseluruhan & 4.60 \\
10 & Aktualitas Materi & 4.50 \\
11 & Kebaruan Materi & 4.50 \\
12 & Kualitas Pembawa Materi (pembicaraan) & 4.50 \\
\multicolumn{2}{l}{ TOTAL } & $\mathbf{4 . 5 8}$ \\
\hline
\end{tabular}

Sumber : Data diolah (2019)

\section{KESIMPULAN}

a. Kegiatan pengabdian masyarakat ini dilakukan dalam bentuk Pelatihan Akuntansi Bank Transaksi Back Office Bank Konvensional. Dalam pelatihan ini peserta pelatihan yang terdiri dari guru dan siswa SMK Unitomo Surabaya mendapatkan materi baik teori maupun praktek tentang 4 bagian yang ada di bank konvensional yaitu bagian giro, bagian deposito, bagian transfer dan bagian kliring.

b. Sebesar $80 \%$ peserta pelatihan telah mendapatkan pemahaman yang cukup baik setelah dilakukan pelatihan yang ditunjukkan dengan nilai post test yang lebih tinggi dibandingkan dengan nilai pre test. Hasil evaluasi pelaksanaan kegiatan juga mendapatkan penilaian yang baik dari peserta pelatihan yang ditunjukkan dengan nilai di atas 4,30. 


\section{UCAPAN TERIMA KASIH}

Penulis mengucapkan terima kasih kepada Pusat Penelitian dan Pengabdian Masyarakat (PPPM) STIE Perbanas Surabaya yang telah memberi dukungan financial terhadap pengabdian ini.

\section{DAFTAR PUSTAKA}

Hadiyati., Fatkhurahman., Suroto, B. (2017). Pelatihan Manajemen Penulisan Karya Tulis Ilmiah Bagi Tenaga Pendidik di SMP N 3 Kampar Kiri Tengah. Dinamisia-Jurnal Pengabdian Masyarakat, 1(1), 122-128.

Haryani, S., Prasetya, A.T., Wardani, S. (2011). Upaya Meningkatkan Keterampilan Guru-Guru Kimia dalam Menerapkan Model Pembelajaran Berbasis Masalah Melalui Kegiatan MGMP, Jurnal Abdimas, 15(2), 93-99.

Karyono. (2010). Pemanfaatam Museum Sebagai Media Pembelajaran Untuk Meningkatkan Pemahaman Siswa Terhadap Materi Prasejarah Bagi Guru-Guru SMA Kota Semarang, Jurnal Abdimas, 14(1), 1-7.

Intihapsari, V \& Hendroanto, A. (2017). Pelatihan Pengembangan Media Pembejaran Flash Guru SMA/SMK Muhammadiyah Se-Kabupaten Gunungkidul. Jurnal Pemberdayaan, 1(2), 427432.

Instruktur Laboratorium Bank. 2018. Modul Klasikal Laboratorium Bank. STIE Perbanas Surabaya.

Nuris, D.M., Suparti., Sulastri. (2018). Pelatihan Penyusunan Perangkat Pembelajaran Berbasis TIK Bagi Guru Akuntansi SMK. Dinamisia-Jurnal Pengabdian Masyarakat, 2(2), 256-260.

Onasis, D., Listihana, W.D., Aquino, A. (2017). Pelatihan Penyusuna dan Penyajian Laporan Keuangan Untuk Usaham Mikro, Kecil dan Menengah Yang Berbasis Standar Akuntansi Keuangan (SAK) entitas Tanpa Akuntabiltas Publik (ETAP) di Desa Muara Jalai Kecamatan Kampar Utara Kabupaten Kampar. Dinamisia-Jurnal Pengabdian Kepada Masyarakat, 1(1), 15-22.

Sadar, M., Syafitri, W., Pane, E. (2016). Pelatihan dan Sosialisasi Sistem Informasi Keuangan Pada Sekolah Islam Terpadu Pekanbaru. Dinamisia- Jurnal Pengabdian Masyarakat, 2(2), 211219.

Utami, S., Sakitri, W., Sebayang, L.K.B. (2016). Peningkatan Kualias Sumber Daya Guru dan Siswa Sekolah Menengah Kejuruan (SMK) Melalui Pengembangan Bahan Ajar Berbasis English Fofr Spesific Purposes (ESP). Jurnal Abdimas, 20(2), 125-132.

Utamiminingsih. (2019). Pelatihan Ecoprint Bagi Kader PKK di Desa Tegalweru Kecamatan Dau Kabupaten Malang. Jurnal Abdimas, 6(1), 28-31. 